\title{
Hypoglycaemic activity of four plant extracts traditionally used in South Africa for diabetes
}

\author{
M.S. Deutschländer ${ }^{\mathrm{a}, *}$, M. van de Venter ${ }^{\mathrm{b}}$, S. Roux ${ }^{\mathrm{b}}$, J. Louw ${ }^{\mathrm{c}}$, N. Lall $^{\mathrm{a}}$ \\ a Department of Plant Science, University of Pretoria, Lynnwood Road, Pretoria, 0002, South Africa \\ ${ }^{\mathrm{b}}$ Department of Biochemistry and Microbiology, P.O. Box 77000, Nelson Mandela Metropolitan University, Port Elizabeth, 6031, South Africa \\ c Medical Research Council, Diabetes Discovery Platform, P.O. Box 19070, Tygerberg, 7505, South Africa
}

\section{A R T I C L E I N F O}

\section{Article history:}

Received 24 November 2008

Received in revised form 20 April 2009

Accepted 25 April 2009

Available online $\mathrm{xxx}$

\section{Keywords:}

$\alpha$-Amylase

$\alpha$-Glucosidase

Hypoglycaemic activity

In vitro

Euclea undulata

\begin{abstract}
A B S T R A C T
Aim: To validate plant species for hypoglycaemic activity.

Materials and methods: Four plants were investigated for hypoglycaemic activity by evaluating inhibiting effects on carbohydrate-hydrolising enzymes: $\alpha$-glucosidase and $\alpha$-amylase. Acetone plant extracts were screened against C2C12 myocytes, 3T3-L1 preadipocytes and Chang liver cells by measuring glucose uptake. Cytotoxicity was done in preadipocytes and hepatocytes.

Results: Extract of Euclea undulata rootbark exhibited highest activity, displaying a glucose uptake of $162.2 \%$ by Chang liver cells at $50 \mu \mathrm{g} / \mathrm{ml}$. An inhibition concentration of $50 \%$ for Euclea undulata was found to be $49.95 \mu \mathrm{g} / \mathrm{ml}$ for $\alpha$-glucosidase and $2.8 \mu \mathrm{g} / \mathrm{ml}$ for $\alpha$-amylase. No cytotoxicity was recorded for Euclea undulata, while Schkuhria pinnata and Elaeodendron transvaalense exhibited cytotoxicity at $12.5 \mu \mathrm{g} / \mathrm{ml}$. $\alpha$-Glucosidase and $\alpha$-amylase assays showed inhibitory activity on enzymes for three plant extracts.

Conclusion: Euclea undulata, Schkuhria pinnata and Elaeodendron transvaalense showed in vitro hypoglycaemic activity. Schkuhria pinnata and Elaeodendron transvaalense indicated cytotoxicity on 3T3-L1 preadipocytes and Chang liver cells. Euclea undulata, Pteronia divaricata and Elaeodendron transvaalense inhibited $\alpha$-glucosidase and $\alpha$-amylase enzymes.

Ethnopharmacological relevance: Screening of plant extracts scientifically validated traditional use of Euclea undulata for treatment of diabetes. Cytotoxicity results revealed that acetone extracts of Schkuhria pinnata and Elaeodendron transvaalense are toxic and raise concern for chronic use.
\end{abstract}

(c) 2009 Elsevier Ireland Ltd. All rights reserved.

\section{Introduction}

Diabetes mellitus is a metabolic disorder characterized by hyperglycaemia and glucose intolerance, either due to insulin deficiency or impaired effectiveness of insulin's action, or to a combination of both. It is regarded as a non-curable but controllable disease. In Africa, diabetes mellitus is no longer a rare disease and recent investigations of non-communicable diseases indicated prevalence from $1 \%$ to $20 \%$ of the population. In South Africa, the prevalence is between $4 \%$ and $6 \%$. The global prevalence was estimated at $2.8 \%$ in 2000 (171 million people) and it is projected that $4.8 \%$ (366 million people) will be affected in 2030 if no action is taken (Wild et al., 2004). The progressive nature of the disease necessitates constant reassessment of glycaemic control in people with diabetes and appropriate adjustment of therapeutic regimens. The burden of the disease is high, not only because life-long treatment

\footnotetext{
* Corresponding author. Tel.: +27 12420 4046; fax: +27 124204601.

E-mail address: miranda.deutschlander@up.ac.za (M.S. Deutschländer).
}

is necessary but also due to the prohibitive cost and unavailability of treatment in rural areas. The rate of limb amputations varies from $1.4 \%$ to $6.7 \%$ of diabetic patients with foot complications and the annual mortality linked to diabetes worldwide is estimated at more than one million (World Health Organization, 2005). If glycaemic control is no longer obtained with a single agent, the addition of a second or third drug is usually more effective than switching to another single agent. Most patients with type II diabetes will ultimately require multiple anti-diabetic agents to maintain adequate glycaemic control (Gerich, 2001). The 2007 World Health Organization Regional office for Africa report stated that one of the strategy aims was to support research in community interventions, including traditional medicine. For these reasons it is essential that the search for new anti-diabetic agents continues.

The most common problem encountered in the detection of pharmacological activity in plant extracts is that even extracts from single plants are mixtures of several compounds, and these can vary in concentration or composition depending on ecological changes (Farnsworth, 1993). Traditional remedies seldom comprise of a 
single plant extract, and in many cases the therapeutic benefits are attributed to the consumption of plant mixtures in which whole plants or plant parts are prepared and consumed in combination (Etken, 1986). This complicates the pharmacological investigation of the preparation, because it has to be determined which of the many constituents of a single plant is active. In vitro screening methods have a further inherent problem in that some compounds showing good activity in an in vitro assay may be metabolized in vivo into inactive metabolites. Conversely, some extracts show only in vivo activity due to the metabolism of inactive compounds into active compounds (Farnsworth, 1993). From the above it is clear that screening activity of plant extracts may vary from batch to batch, however, the continued large scale use of plants in traditional medicines in developing countries such as South Africa necessitates the validation of the use of these plants for various diseases as being effective and safe.

The hypoglycaemic activity of four plant species traditionally used for the treatment of diabetes by South African traditional healers and herbalists was investigated. Species included the small herbaceous weed, Schkuhria pinnata (Lam.) Cabrera Asteraceae. A decoction is prepared from the whole plant and used by traditional healers for the treatment of diabetes in the Ga-Rankuwa area, Gauteng Province, South Africa (Matibe, pers. commun.) (Deutschländer et al., 2009) Pteronia divaricata (P.J. Bergius) Less. Asteraceae, a twiggy, dense shrublet which grows up to $1 \mathrm{~m}$ tall. A tea is brewed from this plant and used in the treatment of diabetes by a traditional healer in the Clanwilliam district, Western Cape, (Maltz, pers. commun.) (Deutschländer et al., 2009). Both Euclea undulata var. myrtina Thunb. Ebenaceae, a dense, erect, evergreen dioecious shrub or small tree and Elaeodendron transvaalense (Burtt Davy) R.H. Archer Celastraceae, a shrub or small, multi-branched tree from 5 to $10 \mathrm{~m}$ tall, are being used in the Venda region of the Limpopo Province of South Africa, by local traditional healers and herbalists for the treatment of diabetes (Tshikalange, pers. commun.) (Deutschländer et al., 2009). A tea is brewed from the rootbark of Euclea undulata var. myrtina and from the stembark of Elaeodendron transvaalense.

\section{Materials and methods}

\subsection{Plant material}

Plant material was obtained from traditional healers as well as collected in the veld at various localities. Schkuhria pinnata (Deutschländer 112982) was obtained from the Medical University of South Africa at Ga-Rankuwa, Gauteng, and additional material was collected from the University of Pretoria's experimental farm. Pteronia divaricata was obtained from a traditional healer in the Clanwilliam district, Western Cape. Euclea undulata (Deutschländer 95254) was collected at various localities in Mpumalanga and Limpopo Provinces whereas Elaeodendron transvaalense was collected in the Venda region, Limpopo Province, (Tshikalange 092524). Plant material was authenticated by Ms M. Nel and Prof. A.E. van Wyk at the H.G.W.J. Schweickert Herbarium, University of Pretoria where voucher specimens are being kept.

Entire Schkuhria pinnata and Pteronia divaricata plants were used for the preparations of the crude extracts. Acetone and ethanol extracts were prepared for Schkuhria pinnata whereas only an acetone extract was prepared for Pteronia divaricata. Acetone extracts were prepared from the rootbark and the stembark of Euclea undulata and Elaeodendron transvaalense respectively. Acetone/ethanol were chosen as solvents as their polarities are close to that of water. An ethanol extract was also prepared for Schkuhria pinnata to compare the hypoglycaemic activity of ethanol and acetone extracts. Results obtained with ethanol and acetone was more or less similar, acetone was chosen as final solvent.

\subsection{Preparation of plant extracts}

Initially the air-dried plant material was ground by using a mill and weighed (Schkurhia pinnata 70 g; Euclea undulata $28 \mathrm{~g}$; Pteronia divaricata $24 \mathrm{~g}$ and Elaeodendron transvaalense $94 \mathrm{~g}$ ). Ground plant material was extracted with acetone except in the case of Schkurhia pinnata, an ethanol extract was also prepared. The volume of solvent varied from 300 to $500 \mathrm{ml}$ depending on the quantity of ground plant material (24-94 g). This procedure was repeated three times to ensure that all possible compounds could be extracted. The filtered plant extracts of the three repetitions were combined and dried by making use of a Rotavapor (Büchi R-114) and liquid nitrogen. The percentage yield obtained for the various plant extracts were as follows: Schkuhria pinnata (1.92\%); Euclea undulata (3.05\%); Pteronia divaricata (4.98\%) and Elaeodendron transvaalense (0.91\%).

\subsection{In vitro anti-diabetic and toxicity screening}

The in vitro anti-diabetic and toxicity screening were done by using an adapted method described by Van de Venter et al. (2008). This method measures glucose utilization, which can be used for long-term exposure of the cells to the sample.

Plant extracts prepared (reconstituted in undiluted DMSO, vortexed and left for $15 \mathrm{~min}$, before further dilution with the respective growth medium) were tested on three cell lines namely; Murine C2C12 myoblasts, Chang liver cells and 3T3-L1 preadipocytes. Hepatic, preadipocytes and myocytes were used because hepatic and, preadipocytes and muscle cells have different glucose transporters, which react differently to insulin stimulation and have different roles in carbohydrate metabolism. This method has the potential to detect not only alterations in glucose uptake, but also any changes that might occur in metabolic pathways where glucose plays a role.

\subsection{Routine maintenance of cell cultures}

All cell cultures were incubated at $37^{\circ} \mathrm{C}$ in a humidified atmosphere with $5 \% \mathrm{CO}_{2}$. The Chang liver and $\mathrm{C} 2 \mathrm{C} 12$ cell lines were fed fresh growth medium every 2-3 days, consisting of RPMI1640 (Highveld Biological, South Africa) medium supplemented with 10\% fetal bovine serum, where as the 3T3-L1 cells were cultured in $\operatorname{DMEM}\left(1.5 \mathrm{~g} / \mathrm{l} \mathrm{NaHCO}_{3}\right.$ ) (Highveld Biological, South Africa) with $10 \%$ bovine serum.

\subsubsection{Glucose uptake experimental procedures in C2C12 myocytes}

Cells in monolayer culture (at $<70 \%$ confluence) were dislodged through brief exposure to $0.25 \%$ Trypsin in PBSA, counted, suspended $(25,000$ cells $/ \mathrm{ml})$ in growth medium (RPMI1640 with $10 \%$ fetal bovine serum) and $200 \mu \mathrm{l} /$ well seeded into new 96 -well plates. The seeded plates were incubated at $37^{\circ} \mathrm{C}$ for $3-4$ days without changing the medium.

To measure glucose uptake, insulin $(1 \mu \mathrm{M})$ was used as positive control whereas $50 \mu \mathrm{g} / \mathrm{ml}$ plant extract (acetone for all four plants as well as ethanol for Schkurhia pinnata) in incubation medium and Glucinet reagent kit (Adcock Ingram) was used to execute the assays.

All medium was aspirated from the cells and $50 \mu$ l of incubation medium/insulin/plant extract added according to the plate well layout and incubated for $1 \mathrm{~h}$. Thereafter $20 \mu \mathrm{l}$ was transferred from each well to a clean well plate and $200 \mu$ l of Glucinet reagent added per well. The plates were incubated at $37^{\circ} \mathrm{C}$ for $15 \mathrm{~min}$ and the absorbance read at $492 \mathrm{~nm}$ using a microplate reader. Due to the short exposure of the $\mathrm{C} 2 \mathrm{C} 12$ myocytes to the plant extracts no toxicity assay was done on this particular cell line. 


\subsubsection{Glucose uptake experimental procedures in Chang liver cells and 3T3-L1 preadipocytes}

Chang liver cells and 3T3-L1 preadipocytes (at $<90 \%$ confluence) were dislodged through brief exposure to $0.25 \%$ Trypsin in PBSA, counted, suspended $(30,000$ cells $/ \mathrm{ml})$ in growth medium (RPMI1640 with $10 \%$ fetal bovine serum) and $200 \mu \mathrm{l} /$ well seeded into new 96 -well plates. The seeded plates were incubated at $37^{\circ} \mathrm{C}$ for 5 days without changing the medium. On day 3 the plant extracts or positive control was administered to the relevant vials according to the plate well layout by adding $10 \mu \mathrm{l}$ extract or positive control to each well to a final concentration of $12.5 \mu \mathrm{g} / \mathrm{ml}$ extract or $1 \mu \mathrm{M}$ metformin (for Chang liver cells). Incubation was continued until day 5 when the glucose uptake experiment was done. The positive control for 3T3-L1 preadipocytes was $1 \mu \mathrm{M}$ insulin but this was only added on day 5 during the glucose uptake experiment in order to avoid the development of insulin resistance. Fifty $\mu \mathrm{g} / \mathrm{ml}$ crude plant extract in the incubation medium (RPMI1640 with $8 \mathrm{mM}$ glucose, $0.1 \%$ BSA) and Glucinet reagent (Sigma) was used to execute the assays as for $\mathrm{C} 2 \mathrm{C} 12$ cells, except that the incubation period was $1.5 \mathrm{~h}$ for 3T3-L1 and $3 \mathrm{~h}$ for Chang liver cells. Toxicity assays were done by adding MTT $(0.5 \mathrm{mg} / \mathrm{ml}$ in RPMI1640: $10 \% \mathrm{fbs})$ to the wells of the last three rows of each plate. MTT is a yellow water soluble tetrazolium dye that is reduced by living cells, but not dead cells, to a purple formazan product that is insoluble in aqueous solutions (Mosmann, 1983). Toxicity results were compared using Student's $t$-test (two-sample assuming equal variances $p(T \leq t)$ two tail) with $p<0.05$ considered significant.

\subsubsection{Dose response assay}

Having obtained the best hypoglycaemic effect from the acetone extract of Euclea undulata, a dose response assay was conducted on Chang liver cells for this extract. The concentration used ranged from 16 to $250 \mu \mathrm{g} / \mathrm{ml}$.

\section{5. $\alpha$-Glucosidase inhibiting activity}

$\alpha$-Glucosidase is an enzyme produced by the villi lining the small intestine of mammals and is responsible for the hydrolysis of disaccharides to monosaccharide that can be absorbed and consequently elevate blood glucose levels. Inhibition of intestinal $\alpha$-glucosidase has been used successfully to treat patients with both type I and II diabetes mellitus (Collins et al., 1997; Hiroyuki et al., 2001).

The $\alpha$-glucosidase inhibiting activity of the four acetone plant extracts was tested following the method described by Collins et al. (1997). This microplate assay offers great convenience, speed and reproducibility. The $\alpha$-glucosidase inhibitory activity was determined by measuring the release of p-nitrophenol from pnitrophenyl- $\alpha$-D-glucopyranose. The released $\mathrm{p}$-nitrophenol yields a yellow colour when the stopping reagent glycine $(\mathrm{pH} \mathrm{10})$, is added.

Two milligrams of the various plant extracts were dissolved in $1 \mathrm{ml} 100 \%$ DMSO to prepare a stock solution and $1 \mathrm{mg}$ Acarbose was dissolved in $1 \mathrm{ml}$ buffer to be used as a positive control (Subramanian et al., 2008). Plant extract stock solutions were subsequently diluted with buffer (1,2-morpholinnoethane sulfonic acid monohydrate-NaOH) (Mes- $\mathrm{NaOH})(\mathrm{pH}$ 6.5) (Fluka 69892) to obtain final concentrations ranging from 200.0 to $0.02 \mu \mathrm{g} / \mathrm{ml}$. The substrate consisting of $1 \mathrm{~g}$ p-nitrophenyl- $\alpha$-D-glucopyranose (Sigma-Aldrich, N1377-1G) was dissolved in $5 \mathrm{ml}$ buffer and incubated at $37^{\circ} \mathrm{C}$ for $15 \mathrm{~min}$. The enzyme ( $\alpha$-glucosidase type 1 from Bakers Yeast) (Sigma 63412) was prepared and used at the highest concentration $(0.58 \mu \mathrm{g} / \mu \mathrm{l})$. The plant extract, positive control, enzyme, buffer and substrate were placed in the 96-well microtiter plate according to the layout to a volume of $200 \mu$ l. After an incubation period of $15 \mathrm{~min}$ at $37^{\circ} \mathrm{C}$ in a Labcon incubator the reaction was stopped by adding $60 \mu$ l glycine ( $\mathrm{pH} 10)$. The absorbance was read at $412 \mathrm{nM}$ in a microtiter plate reader.

\section{6. $\alpha$-Amylase inhibiting activity}

$\alpha$-Amylase is a glycoside hydrolase enzyme that breaks down long-chain carbohydrates by acting on the $\alpha$-1,4-glycosidic bonds, yielding maltotriose and maltose molecules from amylose, or maltose and glucose from amylopectin. Two types of amylase are found in the human body, one in the saliva that breaks down starch into maltose and dextrin, better known as ptyalin and the other pancreatic $\alpha$-amylase that cleaves the $\alpha$-1,4-glycosidic linkages of amylose to yield dextrin, maltose or maltotriose.

The $\alpha$-amylase inhibiting activity of the four plant extracts were tested based on the method as described by Park and Johnson (1949), Bernfeld (1955) and Slaughter et al. (2001). According to this method the reduction of ferricyanide ions in alkaline solutions followed by the formation of Prussian blue (ferric ferrocyanide) is measured quantitatively as basis for the estimation of glucose levels.

The $\alpha$-amylase assay consists of two steps namely the enzyme and the Prussian blue assays.

\subsubsection{Enzyme assay}

The enzyme assay was executed in $32,20 \mathrm{ml}$, Pyrex test tubes according to the experimental layout. Distilled water was added to the test tubes (blank $2.5 \times 10^{3} \mu \mathrm{l}$, negative control $1.25 \times 10^{3} \mu \mathrm{l}$, assay $1 \times 10^{3} \mu \mathrm{l}$ and the colour test $2.25 \times 10^{2} \mu \mathrm{l}$ ). Plant extracts and positive control (Acarbose) were added to the test tubes for the assay as well as for the colour test $(250 \mu \mathrm{l})$ at four different concentrations namely $1.25 \times 10^{3}, 1.0 \times 10^{3}, 7.5 \times 10^{2}$ and $5.0 \times 10^{2} \mu \mathrm{g} / \mathrm{ml}$ (Subramanian et al., 2008). $\alpha$-Amylase Type VI-B from porcine pancreas (Sigma A; 3176-1MU) was prepared fresh by dissolving $20 \mu \mathrm{g}$ porcine pancreatic enzyme in $30 \mathrm{ml}$ ice cold distilled water, sonicated for $15 \mathrm{~min}$ and placed on ice. Enzyme $\left(1.25 \times 10^{3} \mu \mathrm{l}\right)$ was added to the test tubes containing the negative and positive controls as well as the assays and incubated at $25^{\circ} \mathrm{C}$ for $5 \mathrm{~min}$ in a warm water bath. Potato starch (Sigma EC232-686-4) (0.5\%) was prepared by dissolving $60 \mu \mathrm{g}$ in $120 \times 10^{3} \mu \mathrm{l}$ sodium phosphate buffer $(\mathrm{pH}$ 6.9). Starch and buffer solution was heated for $20 \mathrm{~min}$ at a temperature of between 60 and $70^{\circ} \mathrm{C}$. Prepared starch $\left(2.5 \times 10^{3} \mu \mathrm{l}\right)$ was added to all the test tubes and placed in a warm water bath at $37^{\circ} \mathrm{C}$ for $3 \mathrm{~min}$ to activate the enzyme reaction.

\subsubsection{Prussian blue assay}

Thirty two Eppendorf tubes $(2 \mathrm{ml})$ were prepared containing $300 \mu \mathrm{l}$ sodium carbonate $\left(\mathrm{Na}_{2} \mathrm{CO}_{3}\right)$ to which $300 \mu \mathrm{l}$ sample from each of the porcine enzyme test tubes were added and centrifuged. A second set of 32 Eppendorf tubes $(2 \mathrm{ml})$ was prepared containing $950 \mu \mathrm{l}$ of distilled water to which $50 \mu \mathrm{l}$ from the first set of Eppendorf tubes were added.

A second set of 32, $20 \mathrm{ml}$ Pyrex test tubes were used and $500 \mu \mathrm{l}$ of Solution A ( $16 \mathrm{mM} \mathrm{KCN}, 0.19 \mathrm{M} \mathrm{Na}_{2} \mathrm{CO}_{3}$ ) and $500 \mu \mathrm{l}$ of Solution B $\left(1.18 \mathrm{mM} \mathrm{K}_{3} \mathrm{Fe}(\mathrm{CN})_{6}\right)$ was added to each of these test tubes. From the second set of 32 Eppendorf tubes $500 \mu \mathrm{l}$ of sample was taken and added according to the assay layout to the second set of test tubes containing Solution A and Solution B, these were vortexed, covered with foil and placed in boiling water for $15 \mathrm{~min}$, removed and placed at room temperature for $15 \mathrm{~min}$ to cool down. Solution $\mathrm{C}\left(2.5 \times 10^{3} \mu \mathrm{l}\right)\left(3.11 \mathrm{mM} \mathrm{NH}_{4} \mathrm{Fe}\left(\mathrm{SO}_{4}\right)_{2} ; 0.1 \mathrm{~g}\right.$ sodium dodecyl sulphate in $1000 \mathrm{ml} 0.05 \mathrm{~N} \mathrm{H}_{2} \mathrm{SO}_{4}$ ) was added and left for $2 \mathrm{~h}$ and $30 \mathrm{~min}$ in the dark for colour development. The absorbance was read at $690 \mathrm{~nm}$ on a Beckman Coulter DU 720 General Purpose UV/vis spectrophotometer. 


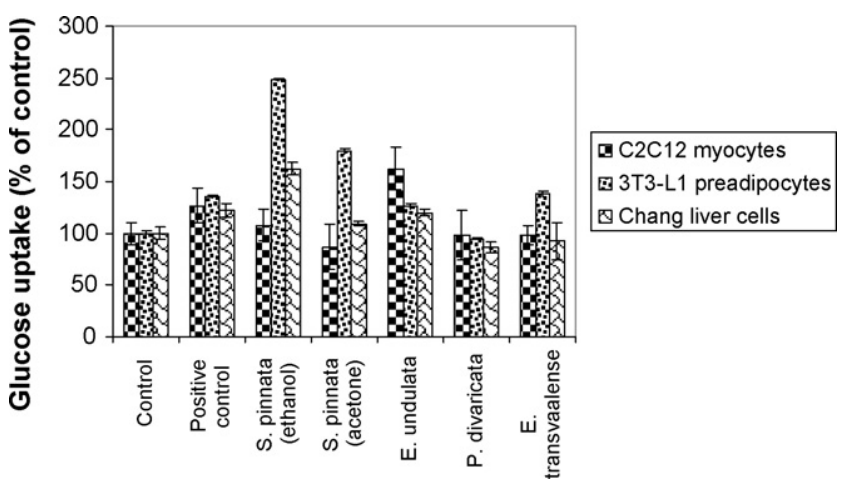

Fig. 1. Glucose uptake (as \% of control \pm standard error of mean, $N=8$ for $\mathrm{C} 2 \mathrm{C} 12$ and 10 for Chang liver and 3T3-L1) of the various plant extracts tested for their hypoglycaemic activity

\section{Results}

\subsection{In vitro}

The results obtained in the in vitro assay on the $\mathrm{C} 2 \mathrm{C} 12$ myocytes on the various plant extracts (at $50 \mu \mathrm{g} / \mathrm{ml}$ ), indicated that Euclea undulata showed some potential in lowering blood glucose levels (162.2\%) as well as Schkuhria pinnata (ethanol) (107.5\%) (Fig. 1). No potential was indicated in Schkuhria pinnata (acetone) (86.8\%), Pteronia divaricata (98.3\%) or Elaeodendron transvaalense (97.7\%) (Fig. 1) extracts. The toxicity of these plant extracts in $\mathrm{C} 2 \mathrm{C} 12$ myocytes was not determined because of the short exposure time of the cells to the plant extracts (Van de Venter et al., 2008).

The in vitro assay in 3T3-L1 preadipocytes indicated that Schkuhria pinnata (ethanol) (248.2\%) and Schkuhria pinnata (acetone) extracts (179.6\%) had some potential to lower blood glucose levels at a concentration of $50 \mu \mathrm{g} / \mathrm{ml}$ as well as that of Elaeodendron transvaalense (138.6\%), and to a lesser extent Euclea undulata (126.0\%) whereas Pteronia divaricata showed no potential (Fig. 1). The toxicity assay revealed, however, that the results obtained with Schkuhria pinnata (ethanol) and Schkuhria pinnata (acetone) extracts were unreliable due to the toxicity of these extracts on 3T3L1 preadipocytes (Fig. 2). It should be noted that the toxic effect was induced by exposure of cells to an extract concentration of $12.5 \mu \mathrm{g} / \mathrm{ml}$ for $48 \mathrm{~h}$ prior to measurement of glucose uptake in the presence of $50 \mu \mathrm{g} / \mathrm{ml}$ incubation medium for $1.5 \mathrm{~h}$.

The in vitro assay in Chang liver cells indicated that Schkuhria pinnata (ethanol) extract (162.3\%) and to a lesser extent Euclea undulata extract (119.7\%) had some potential at a concentration of $50 \mu \mathrm{g} / \mathrm{ml}$. Pteronia divaricata as well as Elaeodendron transvaalense extracts showed no potential (Fig. 1). The toxicity assay revealed, however, that Elaeodendron transvaalense and Schkuhria pinnata (ethanol) extracts were toxic to Chang liver cells (Fig. 2).

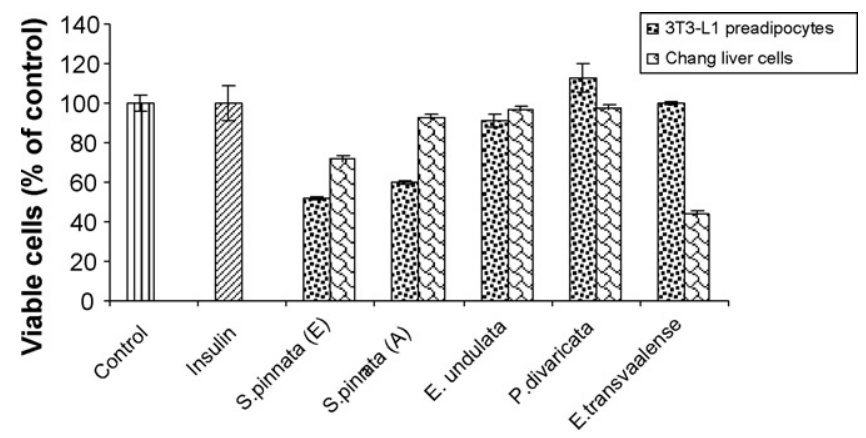

Fig. 2. Toxicity (as \% of control \pm standard error of mean, $N=6$ ) of the various plant extracts tested for their hypoglycaemic activity.
The in vitro assay results indicated that four of the five plant extracts tested namely Schkuhria pinnata (ethanol), Schkuhria pinnata (acetone), Euclea undulata and to a lesser extent Elaeodendron transvaalense showed positive results in increasing glucose uptake in 3T3-L1 preadipocytes, C2C12 myocytes and in Chang liver cells (Fig. 1). Pteronia divaricata showed no ability in increasing glucose uptake.

The results obtained were interpreted by making use of the scoring system developed by Van de Venter et al. (2008) to determine which plant to further analyze. According to this scoring system the potential anti-diabetic activity as well as the toxicity of the plant extract is taken into consideration to assist in the selection of the most active and least toxic plant extract (Table 1).

According to the results obtained from the different in vitro assays done on the various plant extracts Euclea undulata (score +3 ) was chosen for further analysis because, it was not toxic to any of the three cell lines tested and it showed some hypoglycaemic activity in all three cell lines.

Dose response assays were carried out in vitro on Euclea undulata extract to determine the hypoglycaemic effect on Chang liver cells at different concentrations. Fig. 3 depicts the glucose uptake at different concentrations with the highest concentration being at $250 \mu \mathrm{g} / \mathrm{ml}$ and the lowest at $16 \mu \mathrm{g} / \mathrm{ml}$. The highest glucose uptake was obtained at a concentration of $125 \mu \mathrm{g} / \mathrm{ml}(143.4 \%)$ and the lowest at $16 \mu \mathrm{g} / \mathrm{ml}$ (112.1\%). The results obtained were statistically analyzed by making use of the Anova, one-way, post hoc, Tukey HSD test. According to the results, a value of $p<0.05$ were considered significant, obtained at a concentration $125 \mu \mathrm{g} / \mathrm{ml}(0.042) ; 25 \mu \mathrm{g} / \mathrm{ml}$ (0.030); 0.50 (0.00014) and $1 \mu \mathrm{g} / \mathrm{ml}(0.00014)$.

\subsection{MTT toxicity assay}

The MTT toxicity assay revealed that Schkuhria pinnata, ethanol $(p<0.0001)$ and acetone $(p<0.0001)$ extracts were toxic to 3T3-L1 preadipocytes as well as the Elaeodendron transvaalense $(p<0.02)$ extract. The Schkuhria pinnata ethanol $(p<0.0001)$ and the Elaeodendron transvaalense $(p<0.0001)$ extract were also toxic to Chang liver cells (Fig. 2).

\section{3. $\alpha$-Glucosidase and $\alpha$-amylase assay}

The $\alpha$-glucosidase and $\alpha$-amylase $50 \%$ inhibitory concentrations (IC50) for the four different acetone plant extracts, as well as the positive control, Acarbose, is depicted in Table 2 . It is

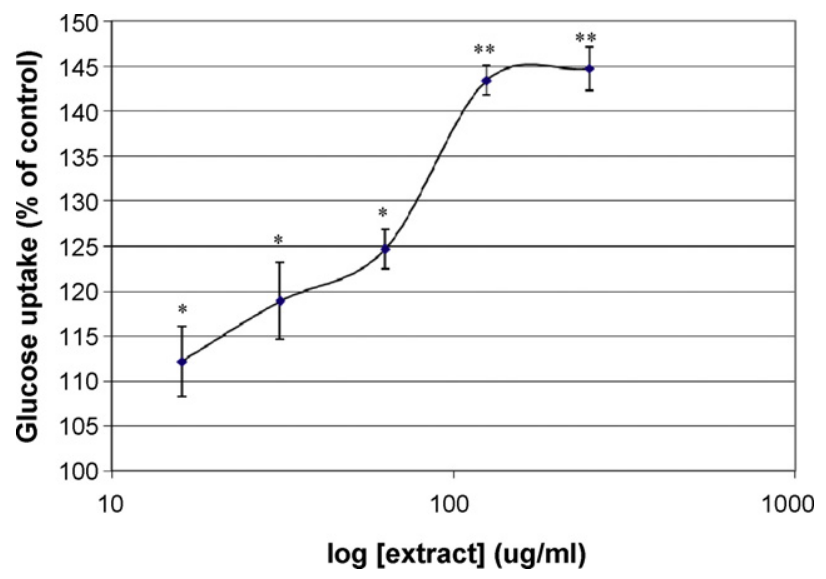

Fig. 3. Dose response of Euclea undulata plant extract in vitro in Chang liver cells (as \% of control \pm standard error of mean, $N=5$ ). Cells were exposed to $12.5 \mu \mathrm{g} / \mathrm{ml}$ extract for $48 \mathrm{~h}$ before glucose utilization was measured in the presence of the extract concentrations as indicated. ${ }^{*} p<0.05 ;{ }^{* *} p<0.005$ compared to untreated control (using Student's two-tailed $t$-test). 
Table 1

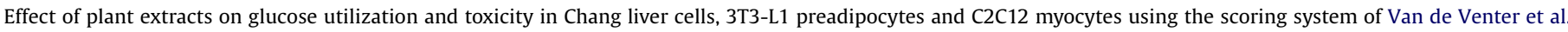
(2008).

\begin{tabular}{|c|c|c|c|c|c|c|c|c|}
\hline \multirow[t]{2}{*}{ Species } & \multicolumn{2}{|c|}{ Chang liver cells } & \multicolumn{2}{|l|}{ 3T3-L1 } & \multirow{2}{*}{$\begin{array}{l}\text { C2C12 } \\
\text { Active }\end{array}$} & \multirow[t]{2}{*}{ Activity score $(\max +6)$} & \multirow[t]{2}{*}{ Toxicity score $(\min -4)$} & \multirow[t]{2}{*}{ Total score } \\
\hline & Active & Toxic & Active & Toxic & & & & \\
\hline Schkuhria pinnata (E) & +2 & -2 & +2 & -2 & 0 & +4 & -4 & 0 \\
\hline Schkuhria pinnata (A) & 0 & 0 & +2 & -2 & 0 & +4 & -4 & 0 \\
\hline Euclea undulata & +1 & 0 & +1 & 0 & +1 & +3 & 0 & +3 \\
\hline Pteronia divaricata & 0 & 0 & 0 & 0 & 0 & 0 & 0 & 0 \\
\hline Elaeodendron transvaalense & 0 & -2 & +1 & 0 & 0 & +1 & -2 & -1 \\
\hline
\end{tabular}

evident from the results that Pteronia divaricata inhibited $\alpha$ glucosidase the most with a IC50 value of $31.22 \pm 0.35 \mu \mathrm{g} / \mathrm{ml}$. From the results obtained with the $\alpha$-amylase assays it was evident that acetone extracts of Euclea undulata and Elaeodendron transvaalense inhibited $\alpha$-amylase most with IC50 values of $2.80 \pm 0.063$ and $1.12 \pm 0.079 \mu \mathrm{g} / \mathrm{ml}$ respectively. IC50 value of $4.75 \pm 3.18$ and $22.92 \mu \mathrm{g} / \mathrm{ml}$ was obtained respectively for the positive control, Acarbose, with $\alpha$-glucosidase and $\alpha$-amylase. Acetone extracts of Schkuhria pinnata showed no inhibition

\section{Discussion}

The in vitro hypoglycaemic analysis revealed that three of the acetone and ethanol plant extracts, namely Schkuhria pinnata, Euclea undulata and Elaeodendron transvaalense, displayed hypoglycaemic activity in one or more of the various cell lines tested. It was also revealed that one acetone plant extract, Pteronia divaricata, showed no hypoglycaemic activity in any of the different cell lines tested. It was however, determined that the high positive values obtained from Schkuhria pinnata could not be considered, as the toxicity assays revealed that the acetone and ethanol plant extracts are highly toxic to 3T3-L1 preadipocytes and the toxicity may have been responsible for the high values obtained in the 3T3L1 preadipocytes in vitro assays. Muthaura et al. (2007) noted a low cytotoxicity of methanol and water extracts of Schkuhria pinnata to Vero E6 cells but no toxicity was observed in in vivo mice tests. The acetone plant extract of Elaeodendron transvaalense also displayed hypoglycaemic activity, but the toxicity assay revealed that it was toxic to Chang liver cells. The only plant extract tested that displayed positive results in all three cell lines and no toxicity was Euclea undulata.

Some anti-diabetic drugs act through inhibition of digestion of complex carbohydrates in the gastrointestinal tract. To determine if some of the plant extracts could act at this level, these plant extracts were tested to determine their inhibition of $\alpha$-glucosidase and $\alpha$-amylase. The results obtained for $\alpha$ -

\section{Table 2}

Inhibitory effect (IC50) of four plant extracts and positive control Acarbose for $\alpha$ glucosidase and $\alpha$-amylase.

\begin{tabular}{ll}
\hline Species & IC50 $(\mu \mathrm{g} / \mathrm{ml}) \alpha$-glucosidase \\
\hline Acarbose & $4.75 \pm 3.18$ \\
Schkuhria pinnata (A) & $\mathrm{NI}$ \\
Euclea undulata & $49.95 \pm 0.007$ \\
Pteronia divaricata & $31.22 \pm 0.154$ \\
Elaeodendron transvaalense & $50.62 \pm 0.351$ \\
& \\
\hline Acarbose & $\mathrm{IC50}(\mu \mathrm{g} / \mathrm{ml}) \alpha$-amylase \\
Schkuhria pinnata (A) & 22.92 \\
Euclea undulata & $\mathrm{NI}$ \\
Pteronia divaricata & $2.80 \pm 0.063$ \\
Elaeodendron transvaalense & $36.30 \pm 4.624$ \\
\hline
\end{tabular}

$\mathrm{NI}=$ no inhibition. glucosidase and $\alpha$-amylase indicated that the plant extracts of Euclea undulata (IC50 49.95 $\pm 0.007 ; 2.80 \pm 0.063$ ), Elaeodendron transvaalense (IC50 50.62 $\pm 0.154 ; 1.12 \pm 0.079$ ) and Pteronia divaricata (IC50 $31.22 \pm 0.351 ; 36.30 \pm 4.62$ ) displayed $\alpha$-glucosidase and $\alpha$-amylase inhibition. Schkuhria pinnata displayed no $\alpha$-glucosidase or $\alpha$-amylase inhibiting activity. Of interest is the fact that Pteronia divaricata did not display any in vitro hypoglycaemic activity but did show some $\alpha$-glucosidase and $\alpha$-amylase inhibiting action, indicating a possible different mechanism through which it could function as an anti-diabetic treatment.

Tshikalange (2007) isolated various triterpenoides such as lup-20(30)-ene-3,29-diol, (3 $\alpha$ )-(9Cl), lup-20(29)-ene-30-hydroxy$(9 \mathrm{Cl})$, taraxastanonol and $\beta$-sitosterol and a phenolic derivative and depside namely ataric acid and atranorin from Elaeodendron transvaalense, these substances were however not tested for their anti-diabetic activity, except $\beta$-sisosterol that demonstrated $\alpha$ glucosidase and $\alpha$-amylase inhibition (Nkobole, 2009). Drewes and Mashimbye (1993) isolated the phenolic compound, elaeocyanidin as well as the gallotannins and ouratea proanthocyanidin A from Elaeodendron transvaalense and it is likely that these compounds are responsible for the hypoglycaemic activity (Gruendel et al., 2007; Gorelik et al., 2008). In literature the use of Schkuhria pinnata as an anti-diabetic agent is numerous but no literature could be found on the chemical analysis and testing for it's hypoglycaemic activity. Zdero et al. (1990) isolated some neryl geraniol derivates, clerodane and three diterpenes form Pteronia divaricata. The triterpenes Betulin and lupeol were isolated from Euclea natalensis by Weigenand et al. (2004) and Khan and Rwekika (1992). According to Sudhahar et al. (2006) lupeol and its derivative normalized the lipid profile in Wistar rats that were fed a high cholesterol diet. Ali et al. (2006) also found that lupeol inhibited $\alpha$-amylase enzyme.

Based on previous phytochemical studies and the results from this study, we conclude that Euclea undulata should be further investigated to identify the compounds responsible for its promising in vitro anti-diabetic activity.

\section{Acknowledgements}

The author would like to thank the Diabetes Research Group in the Department of Biochemistry and Microbiology at the Nelson Mandela Metropolitan University for their support and Prof Gretel van Rooyen for her assistance in the technical editing of the article. This research was financially supported by the National Research Foundation.

\section{References}

Ali, H., Houghton, P.J., Soumyanath, A., 2006. $\alpha$-Inhibitory activity of some Malaysian plants used to treat diabetes; with reference to Phyllanthus amarus. Journal of Ethnopharmacology 107, 449-455.

Bernfeld, P., 1955. Amylase, alpha and beta. Methods in Enzymology 1, 149-158.

Collins, R.A., Ng, T.B., Fong, W.P., Wan, C.C., Yeung, H.W., 1997. Inhibition of glycohydrolase enzymes by aqueous extracts of Chinese medicinal herbs in a microplate format. Biochemistry and Molecular Biology International 42, 1163-1169. 
Deutschländer, MS., Lall, N, Van De Venter, M., 2009. Plant species used in the treatment of diabetes by South African traditional healers: an inventory. Pharmaceutical Biology doi:10.1080/13880200902752959.

Drewes, S.E., Mashimbye, M.J., 1993. Flavanoids and triterpenoids from Cassine papillosa and the absolute configuration of 11,11-dimethyl-1,3,8,10-tetrahydroxyl-9mathoxypeltogynan. Phytochemistry 32, 1041-1044.

Etken, N.L., 1986. Multi-disciplinary perspectives in the interpretation of plants used in indigenous medicine and diet. In: Etken, N.L. (Ed.), Plants in Indigenous Medicine and Diet. Redgrave Publishing Company, New York, pp. 2-29.

Farnsworth, N.R., 1993. Biological approaches to the screening and evaluation of natural products. in: P. Rasoanaivo and S. Ratsimamanga-Urverg, (Eds.), Biological Evaluation of Plants with Reference to the Malagasy Flora, Monograph from the IFS-NAPRECA Workshop on Bioassays, Madagaskar. pp. 35-43.

Gerich, J.E., 2001. Matching treatment to pathophysiology in Type 2 Diabetes. Clinical Therapeutics 23, 646-659.

Gorelik, S., Ligumsky, M., Kohen, R., Kanner, J., 2008. A novel function of red wine polyphenols in humans: prevention of absorption of cytotoxic lipid peroxidation products. FASEB Journal 22, 41-46.

Gruendel, S., Otto, B., Garcia, A.L., Wagner, K., Mueller, C., Weickert, M.O., Heldwein, W., Koebnick, C., 2007. Carob pulp preparation rich in soluble dietary fibre and polyphenols increase plasma glucose and serum insulin responses in combination with a glucose load in humans. British Journal of Nutrition 98, 102-105.

Hiroyuki, F., Tomohide, Y., Kazunori, O., 2001. Efficacy and safety of Touchi Extract, an $\alpha$-glucosidase inhibitor derived from fermented soybeans, in non-insulindependent diabetic mellitus. Journal of Nutritional Biochemistry. 12, 351-356.

Khan, M.R., Rwekika, E., 1992. Triterpenoids from the leaves of four species of the family Ebenaceae. Fitoterapia 63, 375-376.

Mosmann, H.M.T., 1983. Rapid colorimetric assay for cellular growth and survival: application to proliferation and cytotoxic assays. Journal of Immunological Methods 65, 55-63.

Muthaura, C.N., Rukunga, G.M., Chhabra, S.C., Omar, S.A., Guantai, A.N., Gathirwa, J.W., Tolo, F.M., Mwitari, P.G., Keter, L.K., Kirira, P.G., Kimani, C.W., Mungai, G.M., Mjagi, E.N.M., 2007. Antimalarial activity of some plants traditionally used in Meru district of Kenya. Phytotherapy Research 21, 860-867.
Nkobole, N.K. 2009. Anti-diabetic activity of pentacyclic triterpenes and flavonoids isolated from stem bark of Terminalia sericea Burch. Ex DC. MSc dissertation. University of Pretoria, Pretoria, pp. 1-141.

Park, J.T., Johnson, M.J., 1949. A submicrodetermination of glucose. Journal of Biological Chemistry, 149-151.

Slaughter, S.L., Ellis, P.R., Butterworth, P.J., 2001. An investigation of the action of porcine $\alpha$-amylase on native and gelatinised starches. Biochimica et Biophysica Acta $1525,29-36$.

Subramanian, R., Asmawi, M.Z., Sadikun, A., 2008. In vitro $\alpha$-glucosidase and $\alpha$ amylase enzyme inhibitory effects of Andrographis paniculata extract and andrographolide. Acta Biochimica Polonica 55, 391-398.

Sudhahar, V., Kumar, S.A., Varalakshmi, P., 2006. Role of lupeol and lupeol linoleate on lipemic-oxidative stress in experimental hypercholesterolemia. Life Science 78, 1329-1335.

Tshikalange, E.T., 2007. In vitro anti-HIV-1 properties of ethnobotanically selected South African plants used in the treatment of sexually transmitted diseases. PhD thesis, University of Pretoria, Pretoria, pp. 1-112.

Van de Venter, M., Roux, S., Bungu, L.C., Louw, J., Crouch, N.C., Grace, O.M., Maharaj, V., Pillay, P., Sewnarian, P., Bhagwandin, N., Folb, P., 2008. Anti-diabetic screening and scoring of 11 plants traditionally used in South Africa. Journal of Ethnopharmacology, doi:10.1016/j.jep.2008.05.031.

Weigenand, O., Hussein, A.A., Lall, N., Meyer, J.J.M., 2004. Antibacterial activity of naphtoquinones and triterpenoids from Euclea natalensis root bark. Journal of Natural Products 67, 1936-1938.

Wild, S., Roglic, G., Green, A., Sicree, R., King, H., 2004. Global prevalence of diabetes: estimates for the year 2000 and projections for 2030. Diabetes Care 27, 1047-1053.

World Health Organization, 2005. Preventing Chronic Diseases: A Vital Investment WHO Global Report, Geneva, 3 October 2005.

World Health Organization, 2007. Diabetes Prevention and Control: A Strategy for the WHO African Region: Report of the Regional Director: Fifty-seventh Session, Brazzaville, Republic of Congo, 27-31 Augustus 2007.

Zdero, C., Jakupovic, J., Bohlmann, F., 1990. Diterpenes and other constituents from Pteronia species. Phytochemistry 29, 1231-1245. 